\title{
Author Index Volume 8
}

Amri, Puspa D. \& Willett, Thomas D., Policy Inconsistencies and the Political Economy of Currency Crises

1 (2017) 1750004

Chemutai, Vicky \& Escaith, Hubert, Measuring World Trade Organization (WTO) Accession Commitments and their Economic Effects

2 (2017) 1750007

de Serres, Alain, see Sánchez, Aida Caldera

1 (2017) 1750002

Escaith, Hubert, see Chemutai, Vicky

2 (2017) 1750007

Farole, Thomas, see Pathikonda, Vilas

1 (2017) 1750006

Gnangnon, Sèna Kimm \& Iyer, Harish, Structural Economic Vulnerability, Trade Policy and FDI Inflows

1 (2017) 1750005

Gnangnon, Sèna Kimm \& Roberts, Michael, Aid for Trade, Foreign Direct Investment and Export Upgrading in Recipient Countries

2 (2017) 1750010

Gnangnon, Sèna Kimm, Multilateral Trade Liberalization, Export Share in the International Trade Market and Aid for Trade

Goldar, Bishwanath, Parida, Yashobanta \& Sehdev, Deepika, Reduction in Carbon Emissions Intensity and Impact on Export Competitiveness: Evidence from Indian Manufacturing Firms

2 (2017) 1750012

Goyal, Ashima, see Gupta, Satyendra Kumar

2 (2017) 1750011

Guichard, Stephanie, 10 Years after the Global Financial Crisis: What Have We Learnt About International Capital Flows?

3 (2017) 1750017

Gupta, Satyendra Kumar \& Goyal, Ashima, Multiple Reserve Currencies and Renminbi Use

2 (2017) 1750011

Hannan, Swarnali Ahmed, The Drivers of Capital Flows in Emerging Markets Post Global Financial Crisis

2 (2017) 1750009

Hong, Gee Hee, Lee, Jaewoo, Liao, Wei \& Seneviratne, Dulani, China and Asia in Global Trade Slowdown 
Ioannou, Stefanos, Credit Rating Downgrades and Sudden

Stops of Capital Flows in the Eurozone

3 (2017) 1750016

Iyer, Harish, see Gnangnon, Sèna Kimm

1 (2017) 1750005

Lee, Jaewoo, see Hong, Gee Hee

1 (2017) 1750001

Liao, Wei, see Hong, Gee Hee

1 (2017) 1750001

Liu, Yihan \& Westelius, Niklas, The Impact of Demographics on Productivity and Inflation in Japan

2 (2017) 1750008

Molnar, Margit, Revitalizing China's Economy by Improved Corporate Governance and State-Owned Enterprise Reforms

3 (2017) 1750015

Ohnsorge, Franziska \& Yu, Shu, Recent Credit Surge in Historical Context

1 (2017) 1750003

Omoruyi, Ehizuelen Michael Mitchell, The Dragon's Goodwill: Examining China's External Finance and African Leaders' Preferentialism

1 (2017) 1793001

2 (2017) 1750012

Parida, Yashobanta, see Goldar, Bishwanath

Pathikonda, Vilas \& Farole, Thomas, The Capabilities Driving Participation in Global Value Chains

Roberts, Michael, see Gnangnon, Sèna Kimm

Sánchez, Aida Caldera, de Serres, Alain \& Yashiro, Naomitsu, Reforming in a Difficult Macroeconomic Context: A Review of Issues and Recent Literature

1 (2017) 1750002

Sehdev, Deepika, see Goldar, Bishwanath

Seneviratne, Dulani, see Hong, Gee Hee

2 (2017) 1750012

1 (2017) 1750001

2 (2017) 1750008

Westmore, Ben, Sharing the Benefits of China's Growth by Providing Opportunities to All

3 (2017) 1750013

Willett, Thomas D., see Amri, Puspa D.

1 (2017) 1750004

Yashiro, Naomitsu, see Sánchez, Aida Caldera

1 (2017) 1750002

Yu, Shu, see Ohnsorge, Franziska

1 (2017) 1750003 